\title{
“ホタルイ”と総称されるホタルイ属水田雑草の草種について*
}

武田薬品工業株式会社農薬事業部農薬研究所 岩崎桂三・綿島朝次・萩本 宏

ホタルイ (Scirpus juncoides Roxb. var. hotarui Ohwi), イヌホタルイ (S. juncoides Roxb. var ohwianus T. Koyama) およびタイワンヤマイ (S. wallichii Nees）の外部形態はよく似ており，ことに幼植物は酷 似しているので相互に判別することが困難である。その ために, 雑草防除上では上記 3 草種が “ホタルイ” と総 称されていることが多い5)。したがって“ホタルイ”に 関する報告の多くはその草種が明らかでなく, 図版の中 にはイヌホタルイを“ホタルイ”として載せているもの もある。

他方, 岩崎・綿島 ${ }^{2}$ は, 採取した水田表層土壌から出 現したホタルイ属植物の出現率は, イヌホタルイが極め て高く, ホタルイとタイワンヤマイは低かったことを報 告しており, 石倉・曽我1)もイヌホタルイの発生が多い ことを認めている。また, ホタルイのピペロホス・ジメ タメトリン粒剤 (CG 102) およびピペロホス・ジメタ メトリン・ベンタゾン粒剤 (TH 63) に対する感受性 は,イヌホタルイやタイワンャマイよりもはるかに高い ことから ${ }^{3)}$, 著者らは, 水田雑草として防除が問題とな っている“ホタルイ”は, ホタルイそのものではなく, イヌホタルイではないかという疑問を持つに至った。そ こで, 防除の対象となっている “ホタルイ”の草種を明 らかにするためにこの研究を行った。

\section{1. 実験材料および方法}

\section{実験 1. 分㗒された種子からの草種別出現率}

北海道農業試験場, 四国農業試験場, 北海道立上川農 業試験場, 同道南農業試験場, 秋田県農業試験場, 岩手 県立農業試験場県南分場, 宮城県農業センター, 福島県 農業試験場, 長野県農業総合試験場, 千葉県農業試験場, 静岡県農業試験場, 滋賀県農業試験場, 兵庫県立農業総 合センター農業試験場, 岡山県立農業試験場, 高知県農 業試験場, 宮崎県総合農業試験場および日本植物調節剂 研究協会研究所 (茨城県) から分譲された種子を, 1978 年 1 月 7 日から 128 日間, $10^{\circ} \mathrm{C}$ の水中に貯蔵して休眠 を覚醒させた。その種子を, 水田土壃（埴壌土）を詰め た面積 $900 \mathrm{~cm}^{2}(30 \mathrm{~cm} \times 30 \mathrm{~cm})$, 深さ $10 \mathrm{~cm}$ のポット に $126 \sim 500$ 粒播き (1978 年 5 月 15 日), 約 $0.5 \mathrm{~cm}$ の厚 さに覆土した後, 水深 $3 \mathrm{~cm}$ の状態で 21 日間栽培した。
出芽, 生育した植物の中から千葉農試のものは 48 個体, 静岡農試のものは 80 個体, 他の研究機関のものは 90 個 体を任意に抜き取り，前述の土壤を詰めた容量 $430 \mathrm{cc} の$ プラスチック製カップに 1 個体ずつ植え付け，屋外のコ ンクリート製ベッド内で, 水樑 $2 \sim 3 \mathrm{~cm}$ の状態で栽培 した。全個体が出穂, 開花した後に草種を同定し, 草種 別の出現率を調查した。なお，四国農試および秋田農試 からは, 草種を明らかにした種子が分譲された。

実験 2. ホタルイ属植物に対する各程除草侴の効果

ガラス室内で, 水田の埴壤土を詰めた $1 / 5,000 \mathrm{a}$ のワ グナーポットに, 当研究所産のホタルイ, イヌホタルイ およびタイワンヤマイの種子を 30 粒ずつ播き（1978 年 7 月 14 日), 約 $0.5 \mathrm{~cm}$ の厚さに覆土した後, $3 \mathrm{~cm}$ の深 さに湛水した。播種当日（出芽前処理と略称する）ある いは 12 日後（出芽後処理と略称する）に, Table 2 に 示した各除草剤を処理した。なお, 乳剤, 水和剤および $\mathrm{PCP}$ ナトリウム塩は, 1 ポット当たりの所定の薬量を $10 \mathrm{~m} l$ の水に希釈し, この水をポットに静かに流した。 出芽前処理に扔けるホタルイの出芽率は $85 \%$, イヌホ タルイおよびタイワンヤマイの出芽率は共に $100 \%$ で あった。出芽後処理では生育の比較的均一な 15 個体を 残し, 他を間引いて供試した。実験は水深 $3 \mathrm{~cm}$, 無漏 水条件下で行い, 2 反復した。調查は処理 28 日後に行 い，地上部乾物重抑制率（抑制率と略称する）を求め た。

\section{実験 3. ホタルイ属植物の生育地の調查}

京都府福知山市周辺の水田あるいは休耕田で, ホタル イ属植物の生育地を探し出し, ホタルイ, イヌホタル イ, タイワンヤマイそれぞれの発生率およびホタルイが 生育している周囲の植生を調査した。なお, 発生率は, 発生地内を歩いて発見したホタルイ属植物の草種別発生 数（株数）をもって示した。

\section{2. 実 験 結 果}

\section{実験 1. 分㗒された種子からの草種別出現率}

Table 1 に示したように, 草種が明らかにされていた 秋田農試 (イヌホタルイおよびタイワンヤマイ) および 四国農試 (イヌホタルイ) を除き, 分譲された 15 研究 機関の種子から生育した植物を同定したところ, ほとん

*大要は日本雑草学会第 18 回講演会（昭和 54 年 5 月）において発表した。 
Table 1. Identification of the species of Scirpus plants which grew from the seed samples sent from 17 research stations (from Hokkaido to Kyushu).

\begin{tabular}{lcc}
\hline \multicolumn{1}{c}{ Species } & $\begin{array}{l}\text { No. of stations } \\
\text { where each } \\
\text { species appeared* }\end{array}$ & $\begin{array}{c}\% \text { of } \\
\text { Scirpus } \\
\text { plants }\end{array}$ \\
\hline S. juncoides Roxb. var. hotarui Ohwi & 0 & 0 \\
S. juncoides Roxb. var. ohwianus T. Koyama & 15 & $91 \sim 100$ \\
S. wallichii Nees & $3 * *$ & $1 \sim 3$ \\
S. hondoensis Ohwi var. leiocarpus Ohwi & $1 * * *$ & 9 \\
\hline
\end{tabular}

* Exclusion of the seed samples from Shikoku Agricultural Experiment Station and Akita Prefectural Agricultural Experiment Station where the species had been identified. The seed sample from Shikoku Agr. Exp. Sta. was S. juncoides var. ohwianus and those from Akita Pref. Agr. Exp. Sta. were $S$. juncoides var. ohwianus and $S$. wallichii respectively.

** $S$. wallichii appeared in the seed samples from Hokkaido Prefectural Donan Agricultural Experiment Station, Kennan Branch of Iwate Prefectural Agricultural Experiment Station and Shiga Prefectural Agricultural Experiment Station.

*** $S$. hondoensis var. leiocarpus appeared in the seed sample from Hok kaido Agricultural Experiment Station.

Table 2. The effects of various kinds of herbicides on Scirpus juncoides Roxb. var. hotarui Ohwi, S. juncoides Roxb. var. ohwianus T. Koyama and $S$. wallichii Nees by pre- and post-emergence applications under non-water leakage condition.

\begin{tabular}{|c|c|c|c|c|c|c|c|}
\hline \multirow{3}{*}{ Herbicides* } & \multirow{3}{*}{$\begin{array}{c}\text { Rate } \\
\left(\begin{array}{c}\text { a. i. } / \mathrm{hg} \\
/ \mathrm{ha}\end{array}\right)\end{array}$} & \multicolumn{6}{|c|}{$\%$ reduction in dry shoot weight } \\
\hline & & \multicolumn{2}{|c|}{$\begin{array}{l}\text { S. juncoides } \\
\text { var. hotarui }\end{array}$} & \multicolumn{2}{|c|}{$\begin{array}{l}\text { S. juncoides } \\
\text { var. ohwianus }\end{array}$} & \multicolumn{2}{|c|}{ S. wallichii } \\
\hline & & $\begin{array}{l}\text { Pre- } \\
\text { emergence }\end{array}$ & $\begin{array}{l}3.4 \pm 0.2 \\
\text { leaves** }\end{array}$ & $\begin{array}{l}\text { Pre- } \\
\text { emergence }\end{array}$ & $\begin{array}{l}3.4 \pm 0.2 \\
\text { leaves** }\end{array}$ & $\begin{array}{l}\text { Pre- } \\
\text { emergence }\end{array}$ & $\begin{array}{l}3.1 \pm 0.3 \\
\text { leaves } * *\end{array}$ \\
\hline \multirow{2}{*}{$\begin{array}{l}\text { MCPA (ethyl ester) } \\
(1.2 \%, G)\end{array}$} & 0.24 & 97 & 96 & 98 & 85 & 84 & 94 \\
\hline & 0.36 & 99 & 99 & $\fallingdotseq 100$ & 95 & 89 & 97 \\
\hline \multirow{2}{*}{$\begin{array}{l}\mathrm{PCP}(\mathrm{Na} \text { salt }) \\
(86.0 \% \text {, reagent })\end{array}$} & 5.00 & 86 & 85 & 85 & 11 & 98 & 49 \\
\hline & 7.50 & 97 & 96 & 98 & 14 & 100 & 35 \\
\hline \multirow{2}{*}{$\begin{array}{l}\text { Chlornitrofen } \\
(9.0 \%, G)\end{array}$} & 2. 70 & 97 & 98 & 70 & 27 & 60 & 39 \\
\hline & 3.60 & 99 & 98 & 78 & 26 & 72 & 62 \\
\hline \multirow{2}{*}{$\begin{array}{l}\text { Trifluralin } \\
(44.5 \%, E C)\end{array}$} & 0.60 & 0 & 11 & -6 & -35 & -30 & 2 \\
\hline & 0.90 & -13 & 40 & 32 & 7 & -32 & 21 \\
\hline \multirow{2}{*}{$\begin{array}{l}\text { Butachlor } \\
(5.0 \%, G)\end{array}$} & 1.00 & 100 & 97 & 100 & 64 & 100 & 92 \\
\hline & 1.50 & 100 & 94 & 100 & 59 & 100 & 95 \\
\hline \multirow{2}{*}{$\begin{array}{l}\text { Benthiocarb } \\
(10.0 \%, G)\end{array}$} & 2.00 & $\fallingdotseq 100$ & 96 & 100 & 83 & 100 & 56 \\
\hline & 3.00 & $\fallingdotseq 100$ & 98 & 100 & 74 & 100 & 67 \\
\hline \multirow{2}{*}{$\begin{array}{l}\text { Piperophos } \\
(4.4 \%, G)\end{array}$} & 0.88 & 97 & 66 & 99 & 21 & 98 & 39 \\
\hline & 1.32 & 100 & 94 & $\fallingdotseq 100$ & 62 & 100 & 30 \\
\hline \multirow{2}{*}{$\begin{array}{l}\text { Diuron } \\
(78.5 \%, W P)\end{array}$} & 0.40 & 93 & $\fallingdotseq 100$ & 67 & 80 & 43 & 75 \\
\hline & 0.60 & 93 & $\fallingdotseq 100$ & 86 & 70 & 96 & 88 \\
\hline \multirow{2}{*}{$\begin{array}{l}\text { Swep } \\
(40.0 \%, W P)\end{array}$} & 4.00 & 88 & 95 & 76 & 67 & 90 & 84 \\
\hline & 6.00 & 96 & 97 & 94 & 86 & 96 & 94 \\
\hline \multirow{2}{*}{$\begin{array}{l}\text { Simetryne } \\
(1.5 \%, G)\end{array}$} & 0.30 & 99 & 99 & 76 & 62 & -1 & -67 \\
\hline & 0.45 & 99 & 100 & 99 & 88 & -3 & -27 \\
\hline \multirow{2}{*}{$\begin{array}{l}\text { Dimethametryn } \\
(1.1 \%, G)\end{array}$} & 0.33 & 95 & 95 & 31 & 6 & -50 & -67 \\
\hline & 0.44 & 98 & 93 & 45 & 3 & -55 & -4 \\
\hline \multirow{2}{*}{$\begin{array}{l}\text { Bentazon } \\
(10.0 \%, G)\end{array}$} & 2.00 & 85 & 98 & 39 & 94 & 64 & 96 \\
\hline & 3.00 & 84 & 98 & 61 & 96 & 68 & 96 \\
\hline
\end{tabular}

* G : granule, EC : emulsifiable concentrate, WP : wettable powder.

$* * \pm$ S. D., $\mathrm{n}=30$.

- : minus.
どがイヌホタルイであった。タイワンヤマ イは道南農試, 岩手農試県南分場および滋 賀農試の種子から出現したが，出現率はそ れぞれ 3,1 および $2 \%$ で極めて低かった。 また, 北海道農試の種子からはコホタル イ (S. hondoensis Ohwi var. leiocarpus Ohwi）が $9 \%$ 出現した。しかし，ホタル イはいずれの研究機関の種子からも全く出 現しなかった。なお，草種の同定を種子の 形態によっても試みたところ，ホタルイは いずれの研究機関の種子にも混在せず，コ ホタルイは北海道農試の種子にだけ混在し た。イヌホタルイとタイワンヤマイの区別 は刺針状花被片が脱落していたために困難 であった。

実験 2. ホタルイ属辻物に 対する各程除草用の効果

結果を Table 2 に示した。 ホタルイに対して, トリフル ラリン (0.60, 0.90 a. i. kg/ ha）はほとんど効果を示さな かった。しかし, 他の薬剤の 効果は高く, 出芽前処理での 抑制率は $84 \%$ 以上であり， また，葉数 $3.4 \pm 0.2$ 葉，葉 長 $4.0 \pm 0.2 \mathrm{~cm}$ ( $\pm \mathrm{S}$. D., $n$ $=30$, 以下同じ) に生育した 出来後処理での抑制率も， MCPA (エチルエステル; $0.24,0.36$ a. i. $\mathrm{kg} / \mathrm{ha}), \mathrm{CN}$ $\mathrm{P}$ (chlornitrofen; 2.70, 3.60 a. i. kg/ha), ブタクロール (1.00, 1.50 a. i. kg/ha), ベ ンチオカーブ $(2.00,3.00$ a.i. $\mathrm{kg} / \mathrm{ha})$, ピペロホス (1. 32 a. i. kg/ha), DCMU (diuron; 0.40, 0.60 a. i. kg/ ha), MCC (swep; 4.00, 6.00 a. i. $\mathrm{kg} / \mathrm{ha}$ ), シメトリ v (0.30, 0.45 a. i. $\mathrm{kg} / \mathrm{ha})$, ジメタメトリン $(0.33,0.44$ a. i. kg/ha）およびベンタゾ ン $(2.00,3.00 \mathrm{a} . \mathrm{i} . \mathrm{kg} / \mathrm{ha})$ は $93 \%$ 以上, PCP (5.00, 7.50 a. i. kg/ha）では $85 \%$ 
以上であった。

イヌホタルイに対しては, 出芽前処理 において MCPA, PCP, ブタクロール, ベンチオカーブ, ピペロホス， DCMU (0.60 a.i. kg/ha), MCC (6.00a.i. kg/ ha) およびシメトリン (0.45a.i. kg/ha) の処理での抑制率は $85 \%$ 以上であった （薬量を記していない薬剤の薬量はホタ ルイの場合に同じ)。葉数 $3.4 \pm 0.2$ 葉,

葉長 $3.7 \pm 0.3 \mathrm{~cm}$ に生育したものに対す る出芽後処理では, MCPA, ベンチオカ ーブ (2.00 a. i. kg/ha), DCMU (0.40 a. i. $\mathrm{kg} / \mathrm{ha}$ ), MCC (6.00 a.i. kg/ha), シメトリン（0.45 a. i. kg/ha）およびベ ンタゾンの処理での抑制率は $80 \%$ 以上 であった。

タイワンヤマイに対する効果は, シメ トリンを除いて，イヌホタルイに対する とほぼ同程度であった。すなわち, 出芽 前処理での抑制率は MCPA, PCP，ブ タクロール, ベンチオカーブ, ピペロホ ス, DCMU (0.60a.i. kg/ha) および MCC の処理で $84 \%$ 以上であり, 出芽 後処理 (葉数 $3.1 \pm 0.3$ 葉, 葉長 $3.5 \pm 0.2 \mathrm{~cm}$ ) での抑 制率は MCPA，ブタクロール，DCMU，MCC および ベンタゾンの処理で $83 \%$ 以上であった。なお, 出芽前 および出芽後の両処理共シメトリンおよびジメタメトリ ンの効果は認められず, 乾物重はむしろ増加していた (薬量を記していない薬剤の薬量はホタルイに同じ)。

\section{実験 3. ホタルイ属植物の生育地の調查}

京都府福知山市周辺で, ホタルイ属植物が生育してい る場所を調査したところ, 水稲が栽培されている水田内 にはイヌホタルイが圧倒的に多く, タイワンヤマイは一 部で認められたが，ホタルイの発生は全く認められなか った。ホタルイの発生は水田の畦畔 1 個所, 休耕田 4 個 所および著者らの所属する研究所内の水田（水稲が移植 されず，代搔き 85 日後の 1978 年 7 月 12 日に草丈の高 い雑草が刘り取られた, 日当たりの極めて良好な場所） にのみみられた (Table 3)。この研究所内の水田 (A) に発生していたホタルイ属植物は, ホタルイのほかイヌ ホタルイとタイワンヤマイであったが，イヌホタルイが 最も多かった。なお, 水田内でもコナギが密生した部分 には, ホタルイ属植物の発生は認められなかった。ま た, 福知山市大内中地の水田の湿地状態の畦畔 (B) に はホタルイとタイワンヤマイが生育していた。この畦畔
も草が刈り取られ, 調查時には草丈の低いサヤヌカグサ とハイヌメリグサが, ホタルイおよびタイワンヤマイと 共に生育していた。畦畔に近い水田内には発生後まもな いと思われる若いホタルイが多少認められたが，水田の 中心部にはタイワンヤマイだけが生育していた。なお， 同水田の水路の上流にある休耕田にはイヌホタルイとタ イワンヤマイが生育していたが，同水田内にはイヌホタ ルイはなかった。

福知山市大内中地（Bの近くであるが別の所）の休耕 田（C）にはホタルイの発生が極めて多かった。なお, 同休耕田にはカンガレイ (S. triangulatus Roxb.) が 発生していた。休耕後 7 年経過した福知山市後正寺の休 耕田（D）でもホタルイの発生率が高かったが，休耕後 2 年目の加佐郡大江町の休耕田（E）ではイヌホタルイ の発生が多く, ホタルイおよびタイワンヤマイの発生は 少なかった。なお, 同休耕田と水路を隔てて隣接し水稲 の栽培されている水田内には,イヌホタルイとタイワン ヤマイが同程度の割合で多量に発生していた。

このように, ホタルイの発生は休耕田において多く見 受けられ, そのいずれもが湿田あるいは強湿田であり, 特に強湿田である福知山市多保市細田の休耕田 (F) に は, ホタルイ以外のホタルイ属植物の発生は全く認めら 
れなかった。これら 4 個所の休耕田において, ホタルイ の周辺に生育していた植物はミゾソバ, イヌイ, チゴザ サ,コアゼガヤツリ，ヒメクグ，コブナグサなどの比較 的草丈の低い植物であった。

\section{3. 考察}

各地の試験研究機関にホタルイ属植物の種子の送付を お願いしたところ, “ホタルイ”として送付された種子 は，そのほとんどがイヌホタルイであった。タイワンャ マイは, 草種を明らかにして送付された秋田農試以外に は, 道南農試, 岩手農試県南分場および滋賀農試から送 付された種子中から極少数が出現し, コホタルイも北海 道農試の種子中に約 $9 \%$ 混在したが，ホタルイは全く出 現しなかった。このような結果から，ホタルイとタイワ ンヤマイが採種時に意識的に排除されたのでなく，ま た, 発芽率が著しく低かったのでなければ, 雑草防除上 言われるところの “ホタルイ”の多くはイヌホタルイで あることが推察された。分譲された種子を外部形態で同 定したところ，ホタルイは混在せず，また，同時に播い た秋田農試のタイワンヤマイおよび福知山産のホタルイ とタイワンヤマイは正常に出芽, 生育したことから, 両 草種の発芽あるいは出芽に特に問題があったとは考え難 い。これらの種子からホタルイが全く出現しなかったこ とは, 水田ではホタルイはほとんど発生しないか, 発生 しても種子をつくるに到らないことを示唆している。 須藤 ${ }^{5)}$ は, 東北各地の農業試験場から送付された標本中 にホタルイは存在せず, また, 秋田農試の場内にもホタ ルイは存在しないことを報告している6)。著者らが島根 県松江市内の水田および休耕田, 鳥取農試内の水田, 兵 庫県美方郡村岡町の水田や水路, 福井県小浜市, 敦賀市 そして福井市内の水田を探索した時も, イヌホタルイの 発生が最も多く, タイワンヤマイがごくわずかに認めら れたが，ホタルイは発見できなかった。

他方, 京都府福知山市にある著者らの研究所に産した ホタルイ, イヌホタルイおよびタイワンヤイに対して, 我が国で除草剤として単独で，あるいは混合基剤として 使用されている 12 種類の薬阂の効果を検討したところ， トリフルラリンを除くすべての薬剤がホタルイに対して 高い効果を示した。イヌホタルイおよびタイワンヤマイ に対しても高い効果を示した薬剤は, 出芽前処理では MCPA，PCP，ブタクロール，ベンチオカーブおよび ピペロホスであり, 出芽後処理では MCPA およびベン タゾンであった。結局, ホタルイはトリフルラリン以外 のすべての供試薬剤で容易に防除されたことから，系統 による薬剤感受性の相違についての配慮が必要である
が, 雑草防除上問題となっている草種ではない可能性が 高い。

水田雑草としての “ホタルイ”の防除が問題となって きたのは比較的最近のことであり, 日本植物調節剤研究 協会の水稲作関倸除草剤適用性試験成績集に, “木タル イ”が調査対象雑草とされたのも 1973 年度からである。 我が国の水田用初期除草剂として一世を風びした PCP は，1971 年 1 月に水質污濁性農薬に指定されたことも あり ${ }^{4)}, \mathrm{PCP}$ およびその混合製剤の生産および出荷量は 1972 農薬年度以降急激に減少した ${ }^{4)}$ 。前述のごとく, PCP はホタルイ, イヌホタルイおよびタイワンヤマイ の 3 草種に対して出芽前処理で高い効果を示し, その PCP の生産および出荷量の減少と共に“ホタルイ”の防 除が問題化してきたことは，除草剤による weed shift が起きた可能性についても検討する必要性を示唆してい る。また， $\boldsymbol{s}$ るトリアジン系除草剤であるシメトリンとジ メタメトリンが共に，タイワンヤマイに対して全く効果 を示さなかった原因は明らかでないが, 極めて近縁な草 種間の薬剤抵抗性の問題として興味ある結果であると共 に，今後 “ホタルイ”に対する除草効果を論ずるときに はその草種を明確にし, また, ホタルイに対する場合 は, 混乱を避けるために, 学名を付するか,「真正の」 といった形容詞を用いる必要がある。

以上述べてきたごとく, 各地の試験研究機関から送付 された “ホタルイ”の種子中にホタルイは存在せず，ま た, 各種の除草剤に対する抵抗性もホタルイが最も弱か ったことから, 雑草防除上問題にされている“ホタル イ”は, ホタルイそのものではないと考えられる。そこ で，ホタルイが生育している場所を京都府福知山市周辺 で探索したところ, 耕起, 湛水したが水稲を移植しなか った水田内 1 個所, 水田の湿潤な畦畔 1 個所および休耕 田 4 個所でその発生が認められた。これらの場所に共通 していることは, 湿潤であり, 土壌の擋乱や除草剂の施 用がなく, 周囲に存在する他植物は草丈が比較的低く, ホタルイにとって日当たりの良い場所であった。従って ホタルイは除草剤に対する抵抗性だけでなく，他雑草と の競争や人為的な操作に対しても弱いと推察される。ま た，イヌホタルイとタイワンヤマイの薬剤抵抗性に明ら かな相違は見出せなかったが，いわゆる“ホタルイ”は そのほとんどがイヌホタルイであった。この原因は不明 であり，今後の検討課題の一つであるが，水田という生 態系の中での両草種の生理生態学的相違に起因している と考えられるので, ホタルイ, イヌホタルイおよびタイ ワンヤマイの生理生態学的特徴を更に明らかにし，イヌ ホタルイの水田雑草としての成立要因を究明したい。 


\section{4. 摘要}

雑草防除上 “ホタルイ”と呼ばれているホタルイ属植 物の草種を明らかにすることを目的に調查と実験を行っ た。

1） 15 道県，17 個所の試験研究機関から分譲された ホタルイ属植物の種子のうち, 草種が明らかにされてい た 2 農試からの種子を除き, “ホタルイ”として送付さ れた種子はイヌホタルイか, イヌホタルイと低率のタイ ワンヤマイ（３場所）あるいはコホタルイ（1場所）の 混合物であり，ホタルイは全く出現しなかった。

2） 12 種類の除草剤のホタルイ，イヌホタルイおよ びタイワンヤマイに対する効果を検討したところ，トリ フルラリンを除くすべての薬剤がホタルイに対して高い 効果を示した。3草種のいずれに対しても高い効果を示 した薬㶡は, 出芽前処理では MCPA, PCP, ブタクロ 一ル，ベンチオカーブおよびピペロホスであり，出芽後 処理では MCPA およびベンタゾンであった。なお，卜 リフルラリンはイヌホタルイとタイワンヤマイに対して もほとんど効果を示さず，シメトリンとジメタメトリン はタイワンヤマイに対して全く効果を示さなかった。

3）京都府福知山市周辺のホタルイ属植物の生育地を 調查したところ，ホタルイは水田（水稲が移植されてい ない部分） 1 個所，極めて湿潤な水田畦畔 1 個所および 休耕田 4 個所で発生していた。ホタルイと共存していた 植物はイボクサ, サヤヌカグサ, コブナグサ, イヌイ,
チゴザサなどの比較的草丈の低いものであった。また， これら休耕田はいずれも湿田であった。

4）ホタルイは水稲を栽培中の水田では見出せなかっ た。水稲と共存寸るホタルイ属植物はイヌホタルイであ り，わずかではあるがタイワンヤマイが共存することが あった。

謝辞：本研究を遂行するにあたり，ホタルイ属植物の 種子を御恵贈いただいた全国各地の試験研究機関の方々 に感謝する。また，終始熱心に御協力いただいた武田薬 品工業 (株) 農薬研究所研究技員榎原敏男, 出野条太郎 の両氏に感謝する。

\section{引用文 献}

1）石倉教光・㲘我義雄 : ホタルイ属雑草の生態と防除に関す る研究 第 1 報 イヌホタルイ種子の稔実経過と発芽性. 雑草研究 23 (1), 19 23 (1978).

2）岩崎桂三・綿島朝次：ホタルイ,イヌホタルイ及びタイワ ンヤマイの形態的特徵と TH63 粒剤の効果. 雑草研究 22 (1), 24 29 (1977).

3）岩崎桂三・綿島朝次・萩本 宏: ホタルイ,イヌホタルイ およびタイワンヤマイに対するピペロホス・ジメタメトリ ン粒剤およびピペロホス・ジメタメトリン・ベンタゾン粒 剂の効果. 雑草研究 24 (4), 254 259 (1979).

4) 日本植物防度協会：農薬要覧 (1976).

5）須藤孝久: 東北地方のホタルイ類似水田雑草の種類につい て. 雑草研究 20 (2), 87 88 (1975).

6) 須藤孝久：私信 (1977).

(1980 年 3 月 22 日受理)

\title{
Identification of Paddy-field Scirpus Weeds, So-called "Hotarui"
}

\author{
Keizo Iwasaki*, Tomoji Watajima and Hiroshi Hagimoto \\ Research Laboratories, Agricultural Chemicals Division, \\ Takeda Chemical Industries Ltd., Fukuchiyama, Kyoto 620-11
}

\section{Summary}

The present authors tried to make clear a dominant species of Scirpus weeds or so-called "hotarui" in Japanese paddy rice fields.

1. Although Scirpus juncoides Roxb. var. ohwianus T. Koyama was identified in all the seed samples sent from 17 research stations in 15 prefectures, $S$. juncoides Roxb. var. hotarui Ohwi was not at all. $S$. wallichii Nees appeared from 3 seed samples. $S$. wallichii was also sent from Akita Prefectural Agricultural Experiment Station where this species had been separated from S. juncoides var. ohwianus. S. hondoensis Ohwi var. leiocarpus Ohwi appeared from only Hokkaido Agricultural Experiment Station. But their percentages were very low, that is, $S$. wallichii and $S$. hondoensis var. leiocarpus appeared $1 \sim 3$ and $9 \%$ respectively.

2. Eleven kinds of herbicides showed excellent effects on $S$. juncoides var. hotarui by both pre- 
and post-emergence applications. By the pre-emergence application ethyl ester of MCPA, sodium salt of PCP, butachlor, benthiocarb and piperophos showed also high effects on $S$. juncoides var. ohwianus and $S$. wallichii, but only ethyl ester of MCPA and bentazon showed high effects on the above 2 species by the post-emergence application. Trifluralin had no effect on the 3 kinds of Scirpus, and both simetryne and dimethametryn had no effects on $S$. wallichii.

3. In consequence of our investigations on the growing place of Scirpus plants on the outskirts of Fukuchiyama city, adult plants of $S$. juncoides var. hotarui were recognized at only 4 non-cropping paddy fields, a balk and footpath and a non-rice transplanted area in a paddy rice field. It was growing together with short plants in swampy places. But it was never observed in rice-growing paddy field, where almost all Scirpus plants were $S$. juncoides var. ohwianus.

4. The noxious "hotarui" in Japanese paddy rice fields must be $S$. juncoides var. ohwionus.

* Present address: Development and Sales Promotion Department, Agricultural Chemicals Division, Takeda Chemical Industries Ltd., 12-10 Nihonbashi 2-chome Chuo-ku Tokyo 103. 